direct the sending of the findings of the Judiciary Committee to each member.

RULe 8. Publication of Exoneration. - Should the Committee on Practice fail to find a prima facie case, it shall so advise the Board of Directors, for record, and the accused and accuser. Should the Judiciary Committee exonerate any accused member, the Secretary of the Board shall so advise the accused and accuser, and if requested by the accused shall forward a copy of its findings for publication in The Journal, in addition to the sending of such findings to each member of the Institute.

RULe 9. Service of Secretary's Office. -The Committee on Practice and the Judiciary Committee may call upon the Secretary of the Institute for the assistance of his clerical force in the work of their committees, and it shall be the duty of the Secretary to furnish such assistance.

\title{
The Architectural Student and His Relation to Professional Practice
}

\author{
By EMrr Lorch \\ Professor of Architecture, University of Michigan, Member of the American Institute of Arch- \\ itects and President of the Association of Collegiate Schools of Architecture
}

Y OUNG men enter the architectural profession along two principal lines. Many attend an architectural school and then enter an architect's office for practical experience before engaging in independent practice; others enter such an office directly after attending high school or after pursuing a liberal arts or a scientific course at college.

The recruit's understanding of professional and ethical relations depends largely on the manner in which he has received his general and professional education, upon the kind of approach he makes to his profession and to his duties as a citizen. This approach has varied with conditions, the status of the profession before the public and the profession's realization of its duty.

As a people projects its conception of behavior in the form of law, so a profession when it becomes conscious of its obligations formulates certain regulations for its followers. A standard is set up for membership and good standing in the professional organization and this organization, with the consent of those governed, exercises disciplinary powers in the way of censure, suspension, or expulsion against offenders. Such an organization does a real educational work for the public and the entire profession concerned, gradually creating an understanding of the aims of the profession and giving it a more definite place in the general economic and social fabric.

After attaining a measure of public recognition, it becomes possible to proceed further and establish a basis of admission to the profession by requiring candidates to qualify educationally under a state law, thus protecting the publicto some extent against incompetence, gaining the recognition of the state for the profession, and making possible disbarment from practice of those flagrant offenders against public interest who could not be reached through any code of a purely selective organization.

The organization of a profession with definite and published ideals of performance, seconded by a legal minimum of admission to practice for all, irre- 
spective of membership in professional societies, constitutes evidence which should make clear what the profession stands for in point of preparation and professional relations, ethical and otherwise.

\section{The Apprenticeship System}

Before the organization of the American Institute of Architects, of the architectural schools, of architectural publications, and of registration laws, the architectural recruit received his technical and social training as the apprentice of an architect. In England he was "articled" in a professional rather than a commercial office and paid for his instruction and other privileges. The architect was morally bound to further his education, while there was a social side to the relation which tied together student and practitioner. The problems of the office were shared with the apprentice in proportion to his advancement and the personal association of master and pupil nurtured a professional sense, with a sympathy for as well as understanding of professional obligations. Here was a bond which made for fine coöperation and respect for the interests of the public and other practitioners, and created a solidarity which is still powerful in England.

America inherited and modified the apprenticeship system, long retaining its valuable contacts and handing on of knowledge. The beginner entered the office, however, more or less as a general "cub" assistant, doing everything until he finally became a fullfledged draftsman, often later becoming a member of the firm. Here, too, the system engendered loyalty and mutual respect, and in numberless cases the architect gave freely of himself to the rising generation to better the profession. Here again the personality of the practitioner and his older assistants counted tremendously in molding the beginners. These beginners were generally very young and had had little general schooling, gaining their insight of the larger relations, their world outlook, while learning how to draw, and studying at night such books as could be had. It was a highly individual process, which often left too much to the initiative of a student of very modest attainments, slight background and limited opportunities for improvement outside the office. During this period there was no approximate agreement as to the larger relations of the architect or his education, little vision as to the possibilities of architecture, and hence the beginner's introduction to the professional field varied greatly with the office where he served his apprenticeship.

\section{Organization of the Architec- TURAL SchOOLS}

The organization of architectural schools began in this country soon after the formation of the American Institute of Architects and their growth has rapidly displanted the apprentice system. There was a transitional period during which the value of an architectural school training was questioned by those who had come up through the other system but for some years now it has been assumed that proper preparation for the profession consists of such schooling along with the practical experience, like the physician's interneship, which must precede independent practice.

While many young men still begin in an architect's office, practically all now look forward to attending an architectural school. This change is entirely owing to higher standards of practice and the greater demands made on the profession, the rapid progress made by graduates, their greater breadth of view, and the preference of most architects for trained assistants. 
There has been a significant parallelism between the evolution of the American Institute of Architects, the colleges, universities, architectural schools and journals. It is safe to say that the schools have markedly influenced the architectural profession and that the profession's better conception of its obligations reflects much that the colleges in general stand for. Schooled men have for many years been taking over control of the Institute and, thus placed, have shaped many of its activities. The agencies enumerated above reflect, in turn, the general development of the country, its organization of industry and business, its large projects and need for hurried production, out of which has sprung the large architectural office organization for practice.

About one-half of all architectural draftsmen are employed in such organizations and in them the individual is but a cog, rarely coming into personal contact with a member of the firm. In such offices, specialization obtains as a natural outgrowth in the fields of design, construction, mechanical and other equipment, specifications, superintendence, rendering and other parts of the work; some portions of this work may even ba done outside the office by other technical organizations, while the actual building operation may not be observed at all by many of the assistants who are busy throughout the day at the drawing board and thus do not see the expression in real materials of what they have drawn. They have little contact with the actual work or with the architect. As a consequence of this specialization and mechanicalization, some young men will not work in a larger office if they can possibly get into a smaller one where they can better gain a conception of the entire range of activities and have a share in more of them.
To overcome this difficulty, a splendid effort was recently made in one office to discuss the current work once a week with the entire drafting force in order to give them some insight into the conditions under which the office was serving and to bring about better mutual understanding and team play.

Clients have been known to point out that the assistants in some offices had progressed little in certain directions over a period of years, because they had been so closely tied down and had been given no opportunity to go out on the building, visit modelling and other craft-shops, and thus gain a greater sense of the reality of what they drew. Today in large offices the old bond between master and pupil is uncommon; the assistant does certain assigned tasks, works as a member of a squad and gains little attachment for his employer and no great enthusiasm for his work; close interdependence and personal interest and contact are too often wanting and the recruit gets little idea of the profession as a whole. Hence the increased necessity of discussing the problems and ideals of the profession in draftsman and student clubs and in the architectural schools.

After the formation of the American Institute of Architects in 1857 there gradually came about a crystallization of thought on matters affecting the profession and its larger objectives and as a consequence there has for years been growing up a series of documents on professional practice known as the "Ethical Documents of the American Institute of Architects." These are unique and authoritative as well as comprehensive and succinct statements, which have had considerable influence outside of Institute circles. They are available to all practitioners and students. Successive committees of the Institute have worked devotedly to produce and clarify these documents. 
In them are defined the responsibilities of the architect to those he serves and to the contractor, as well as to other architects.

\section{Education in Professional Relations}

The Institute was quick to see that it must concern itself not only with practice but also with education. The Committee on Education has with increasing understanding coöperated with the schools. Special sessions of the Institute conventions have been devoted to education, exhibitions of students' and architects' work have been held, the leading schools recognized, and medals awarded to promising students.

The aims and activities of the Institute and the subjects included in the Institute documents are now discussed in one form or other in practically every architectural school, but with varying emphasis. In some, the curriculum is so overcrowded that little time can be allowed for such discussion. Where an entire course in professional relations is permissible, the titles "Professional Practice," "Professional Relations," "Specifications and Practice," "Business Law," "Business Administration," "Contracts," and the like are frequently used and "Ethics" is formally discussed as part of the course.

This is one of the fields in which the visiting lecturer can do most effective work and such lecturers alone give the instruction in one school; in others, visiting lecturers share the instruction with regular instructors. An examination is given at the close of such a course. In two schools, but one and four lectures respectively are given to the class about to graduate. Again, where no special course is given, the professor of architecture discusses professional relationship at meetings of the student societies or as part of other class instruction. In two schools, the freshmen hear about it and the subject is constantly kept before the students. Where the subject is not actually taught, it is proposed to give formal instruction very soon.

One of the school heads to whom the writer wrote to learn what was being done in the institution of which he has charge, after referring to bad conditions in his particular state, said: "It is a big problem, but we are making a beginning and the next generation will feel the effect."

The essence of the Institute documents is given in the "Circular of Advice" and the "Canons of Ethics," both of which are printed in full in this volume. ${ }^{1}$ The fundamental thought of these is the maintenance of truly professional relations by the architect to the owner and the contractor; while employed and paid by the owner and remaining loyal to him, the architect, as interpreter of the conditions of the contract and judge of its performance, must retain impartiality in order to be just to the contractor. Fairness to other architects, advertising, non-participation in improper competitions, duties to students and draftsmen and to the public and building authorities, professional qualifications and the architect's status are briefly summarized in the above documents and in the syllabi of some of the schools, as is also the gist of the "Circular of Advice on Architectural Competitions," "Disciplinary Rules" and the "Schedule of Charges," the business forms, general conditions for specifications, and the form of contract. Most of these are discussed in some measure in the schools, but there is considerable room for more systematic and thoroughgoing attention to them.

In one school critical and other

${ }^{1}$ Seb page 277. 
articles bearing on the profession and architectural education are read and discussed by the senior class to give students another angle of current thought. In two schools summer office work is required and two summer vacations must be spent in this way before the diploma is granted. Students thus get some insight into office routine, profit more by class instruction and, upon graduation, more easily get a start as draftsmen.

At least one division of the architectural curriculum is of particular worth in combining technical knowledge with more general values. In architectural history there is not only the great chain of human events reflected in monuments but high ideals of performance, distinguished personalities and extraordinary examples of achievement. Devotion, self-sacrifice and genius are all found here. Like architectural design, this is one of the truly inspirational subjects of architectural teaching.

To students the wide field of effort of the Institute also needs to be interpreted, as it does to some who never attend a convention and thus fail to grasp the reality and vitality of the organization. Its purpose is best demonstrated in the manifold activities reflected at the annual convention, at which time all the many standing and special committees report. It would be a splendid experience for students to sit through such sessions and thus learn what a large number of busy men in all parts of the country are unselfishly contributing through committee activities to the evolution of the Institute ideal and to giving it practical effect.

\section{Adjustment to the Profession}

It has been said above that in some schools little attention is given to "professional practice" because the curriculum is overcrowded. In the so- called four-year courses in architecture there is little time available for cultural and scientific subjects in addition to essential preparatory and technical work. Some hold, moreover, that given a reasonably broad collegiate and technical training, the graduate will, while getting practical experience prior to independent practice, readily come to grasp the principles involved in such practice with the help of the very concrete, definitely expressed documents published by the Institute.

The entire professional student career is obviously one of adjustment to the profession. Its obligations are constantly kept before him; the bearing of each principle and technical topic on actual circumstances is carefully discussed. If the school cannot anticipate the actual experience of the individual it can and must help train and form him, strengthen his convictions for the time of struggle and doubt, and place him in the larger currents of thought. Although the college period has among its drawbacks, in the minds of ardent realists, the keeping of the student away from actual business problems and life, it has, derived from this, the very advantage that it may help form character which will help build a better world. Idealism certainly finds one of its strongholds in our institutions of learning. The fundamental ideal of the college is, after all, to increase resource and power; to develop men, to train them for good citizenship rather than narrow vocationalism or professionalism. They must be able to do their elected work, but they must also be prepared to give whole-hearted coöperation to the furtherance of civic, state and national well-being.

To the college period the student comes more definitely influenced by standards of private than of public life. His reactions to questions of 
honesty are already largely formed. During this periodhechangesfrom boyhood to manhood and receives a better understanding of life and the relation of the individual to it. If he can give time to a fair amount of liberal or cultural studies, he will more readily understand human relations and learn to distinguish ethical values. If, however, he immediately enters the customary limited professional course of but four years in architecture based on high school training, thus allowing very little time for cultural studies, the likelihood of his having a good general conception of the normative field is greatly lessened, for his chief preoccupation will be to make a practical success as soon as possible after graduation.

The group trained as first suggested through its analysis of form, character and events, study of literature, sociology, economics, political science, law and philosophy in its various forms including ethics, needs little in the field of professional ethics. These men come from the university with a fairly good understanding of human relations and may be trusted in their relations to society or a specific group, professional or otherwise. For the second group a discussion of the ideals of the profession is much more needed. In any case, the institution can only send out its graduates with the hope that in an age in which so much has been commercialized they will distinguish values and keep up to the highest possible mark and that they will help form an opinion which will raise the general standard of performance.

After graduation those who have the means will in increasing numbers go abroad for study and travel before entering an architect's office for a period of apprenticeship and experience before becoming practitioners.

\section{Conditions of Entrance to Practice}

Independent practice in former years depended merely on securing some kind of commission or client but in at least twenty-two of our states men must now qualify for practice under registration laws. The young architect thus receives formal recognition by the state with a certain measure of confidence on the part of the public, as in the case of the doctor and the lawyer. In some states candidates for the examination must have two or three years' experience under an architect in addition to a diploma. The Institute has been very conservative on this question and not until three years ago did it give its support to the principle involved. In the minds of many, such laws provide the best means for protecting the public against those utterly lacking in fitness and training for even the lesser responsibilities and smaller problems of the architect. Such laws have very great possibilities for good, have been in effect long enough to demonstrate real value, and give students an objective similar to that of other recognized professions.

The architectural schools have long realized the necessity for higher standards of admission and graduation. At the universities they are directly in touch with the higher requirements effective for law and medicine and have recently won the support of the Institute for longer courses which are to be given effect in the near future. To encourage sound effort, the Institute has for some years awarded a medal annually to that graduating student of each of the "recognized" schools who has stood highest in his class throughout the duration of the course. A number of architects have been able to provide resident scholarships for deserving students and foreign travelling 
scholarships to create an interest in higher artistic achievement through a first-hand acquaintance with master works. Much more can and should be done in this direction, for every architectural student should know at first hand some of the great works of the artistic field abroad, not only in architecture but in painting, sculpture, gardening and city planning.

\section{Extra-Classroom Forces in Ethical Training}

The sense of individual responsibility is developed by allowing students opportunities for activities outside of class work; thus they begin as class officers, serve on committees or student publications, engage in athletics, debates, entertainments, and the like. Such activities develop initiative and a knowledge of men and affairs which are of great value and mean much to the college student. Most of his life is spent outside the classroom, away from the faculty, and thus his associates, amusements, club or fraternity connections have much to do with shaping his ideals. In most cases he retains the religious affliations made at home and where this is so, a potent constructive force exists for good, probably stronger in so-called denominational institutions than in the others. Practically every architectural school has its student architectural society with its list of speakers, architectural and otherwise, while there are two national architectural fraternities, the members of which have club houses managed by students at their respective institutions, as do certain other professional student groups. There are also two national honor fraternities for architectural students, also under student control and open only to a certain percentage of the students on the basis of high scholarship, a qualification which demonstrates the effect of student initiative in the recognition of good personality and work.

In institutions where the honor system prevails, where the students themselves undertake supervision of examinations, we have another positive force for good. It will be gratifying to some to know that students have been known to vote down the honor system for examinations, since the men felt that they were on their honor continuously! In some colleges, under such a system, students offending against the code are tried by a student honor committee and if found guilty are dismissed from college by that committee; in other institutions, the findings of the student committee are reported to the faculty concerned, which acts on the recommendation of the honor committee. Nothing can be finer than the willingness of students to accept such a responsibility and nothing will better prepare them for some of the burdens of professional life. 